\title{
Lifetime utilization of mammography among Maltese women: a cross-sectional survey
}

Danika Marmarà ${ }^{1,2^{*}}$ (D) Vincent Marmarà ${ }^{3}$ and Gill Hubbard ${ }^{1}$

\begin{abstract}
Background: The knowledge of Maltese women not attending the Maltese Breast Screening Programme (MBSP) for mammography screening is scarce. Previous research has identified two distinct groups of non-attendees: those who do not attend because a mammogram was taken elsewhere and those who never attended for mammography anywhere. It is however unknown which determinants are predictive of lifetime attendance 'anywhere' and 'real' nonattendance. The present study examines the relationship between ever-using (Lifetime attendees) or never using mammography (Lifetime non-attendees) and psychosocial - as well as sociodemographic factors, with the aim to identify predictors that can inform practice.
\end{abstract}

Methods: Women's characteristics, knowledge, health beliefs and illness perceptions were compared, based on prior data of 404 women, aged 50-60 years at the time of their first MBSP invitation. The main variable of interest described women's attendance to mammography (LIFETIME ATTENDEES) and no mammography (LIFETIME NON-ATTENDEES). Data were analyzed using descriptive statistics, chi-square tests, Mann Whitney test, Independent Samples t-test, Shapiro Wilk test and logistic regression.

Results: During their lifetime, $86.1 \%$ of Maltese women $(n=348)$ were attendees, while $13.9 \%(n=56)$ were non-attendees. Non-attendees were more likely to be women with a lower family income $(x 2=13.1, p=0$. 011), widowers ( $x 2=9.0, p=0.030)$, non-drivers $(x 2=7.7, p=0.006)$, without a breast condition $(x 2=14.2, p<0.001)$, who had no relatives or close friends with cancer $(x 2=8.3, p=0.016)$, and who were less encouraged by a physician $(X 2=4.9, p=0.027)$, unsure of the screening frequency $(X 2=28.5, p<0.001)$, more anxious $(p=0.040)$ and fearful $(p=$ 0.039). Perceived benefits, barriers, cues to action, self-efficacy and emotional representations were the most significant variables to describe the differences between lifetime attendees and non-attendees. Perceived barriers and cues to action were the strongest predictors for lifetime non-attendance ( $p<0.05$ respectively).

Conclusions: The health beliefs of women who have never attended for mammography during their lifetime should be targeted, particularly perceived barriers and cues to action. Further research should focus on understanding knowledge gaps, attitudinal barriers and emotional factors among 'real' non-attendees who require a more targeted approach.

Keywords: Breast cancer, Mammography, Attendance, Non-attendance, Health beliefs, Illness perceptions

\footnotetext{
* Correspondence: attard.danika@gmail.com

${ }^{1}$ Faculty of Health Sciences, University of Stirling, Room E9, Pathfoot, Stirling

FK9 4LA, Scotland

${ }^{2}$ Ministry for Health, Cancer Care Pathways Directorate, Sir Anthony Mamo

Oncology Centre, Level -1, Dun Karm Psaila Street, Msida MSD 2090, Malta

Full list of author information is available at the end of the article
}

(c) The Author(s). 2018 Open Access This article is distributed under the terms of the Creative Commons Attribution 4.0 International License (http://creativecommons.org/licenses/by/4.0/), which permits unrestricted use, distribution, and reproduction in any medium, provided you give appropriate credit to the original author(s) and the source, provide a link to the Creative Commons license, and indicate if changes were made. The Creative Commons Public Domain Dedication waiver (http://creativecommons.org/publicdomain/zero/1.0/) applies to the data made available in this article, unless otherwise stated. 


\section{Background}

Breast cancer $(\mathrm{BC})$ is the most common type of cancer in women worldwide [1]. In Malta, it has topped the list of female cancers and has accounted for an average incidence of over 280 women over the last 12 years [2]. Early detection of $\mathrm{BC}$ renders the possibility of efficient treatment [3] which would more likely include breast conservation without chemotherapy [4]. Regular use of mammography screening at short enough intervals is a cost-effective way [5] to detect tumours early enough in order to improve prognosis, reducing mortality and thereby impacting on survival $[4,6,7]$.

Across the globe, lifetime utilization and regular reutilization of mammography has been increasing steadily across the years [3, 7-9]. Despite the known benefits of breast screening (BS) by mammography [10-12], also referred to as mammography screening (MS), various countries have still not reached the recommended acceptable $(>70 \%)$ or desirable $(>75 \%)$ EU benchmarks, according to the European Guidelines [13]. Lower utilization rates may be associated with three main factors: (a) logistical determinants such as the availability and accessibility of a screening center, test affordability, time from work or travelling time [3, 14, 15], (b) psychosocial factors such as values, expectations and beliefs which affect the way women transform knowledge regarding mammography into actual behaviour [16], and (c) socio-demographic determinants which impact on the way structural and psychosocial factors predict mammography use [17, 18]. However, most of the literature does not take into account the context of mammography provision, such as countries with dual health systems (organized and private screening).

Although general barriers to screening by mammography in Malta have been identified in our earlier study [19], our findings showed that our screening cohort consisted of attendees and non-attendees to the Maltese Breast Screening programme (MBSP); however, we recognised that the MBSP non-attendees consisted of a heterogeneous group of women with diverse reasons for non-attendance. Hence, screening non-attendees were not a single group of non-compliant Maltese women, but consisted clearly of two distinct subgroups:

(i) Women, who had obtained a mammogram outside the MBSP, possibly as a self-initiated action or routine check-up [15] or as part of private breast awareness campaigns, which may have been based on their recognition of susceptibility to $\mathrm{BC}$ and high self-efficacy in preventing BC [20], and

(ii)'Real' non-attendees i.e. women who have never attended anywhere for mammography during their lifetime.
Considering the fact that the Maltese National Health System (NHS) comprises both the public and private sectors, and that a national breast screening programme was introduced at the end of 2009 for women aged 50-60 years at the time [13], some women chose to go privately for a mammogram before the year 2009 and still do so to date rather than taking up the invitation to be screened at the MBSP. However, it is the diversity of 'real' non-attendees [15] that needs to be better understood in order to develop culturally sensitive interventions.

Nothing is yet known to date about those who never attend for mammography throughout their lifetime in Malta. Hence, this study was carried out to provide an understanding of the determinants of lifetime mammography screening behaviour among Maltese women who attend 'anywhere' and those who have 'never' attended for mammography. This paper is "part two" of a larger study that was conducted on breast screening uptake in Malta carried out through a national cross-sectional survey and hence, this paper is a continuation of that previous article. In this paper, data from that 2015 Maltese national survey were used to assess the relationships of lifetime mammography utilization (attendance 'anywhere') and 'real' non-attendance with sociodemographics, health status, knowledge, health beliefs and illness perception variables, based on the Health Belief Model (HBM) and Common-Sense Model (CSM). Both HBM and CSM have been used as theoretical frameworks to predict the uptake of mammography screening [21-24]. The CSM has been used to consider the cognitive and emotional representations of an illness [23] which are often omitted in the use of HBM. On the other hand, the CSM does not describe the perceived barriers and benefits to the performance of healthrelated behaviours [21] such as mammography use, and excludes the role of significant others such as family, friends and healthcare providers [25]. By contrast, the HBM addresses all of these, incorporating the components of perceived benefits, perceived barriers and cues to action. Following the simultaneous use of both models which were found to improve the prediction of non-attendance to the MBSP in our earlier study [19], both models were again utilised to integrate the beliefs about the illness (CSM) [26] and the individual's beliefs on the recommended behaviour [HBM] [21] in this study on lifetime mammography utilization.

Guided by the guidelines 'Strengthening the Reporting of Observational Studies in Epidemiology' (STROBE) [27] [see Additional file 1], we built on the findings of our prior study [28] which suggest that health beliefs and illness perceptions vary between women who accept or refuse a BS invitation to the organized programme. The immediate aim of our study was to gain an understanding of the determinants of lifetime mammography 
use among women who attend for mammography 'anywhere' and those who never attend for mammography during their lifetime ('real' non-attendance).

\section{Objectives}

In reaching our aims, this analysis has targeted the following objectives:

(1)To determine the socio-demographics, health status, knowledge, health beliefs and illness perceptions of women who attend or do not attend for mammography screening during their lifetime;

(2) To examine the most significant predictors of lifetime mammography utilization and its non-use.

\section{Methods}

\section{Design and setting}

Since this study was part of a 2015 national retrospective study, the full details of the methods are described elsewhere [19]. The MBSP was set up to serve as the only centre in Malta to offer national screening as part of an organized programme. As is the current practice at the MBSP, two views (medio-lateral and cranio-caudal) are carried out by trained radiographers (mammographers) and the mammograms are reported by trained breast radiologists. Adjunct ultrasound is carried out at a subsequent (recall) appointment when deemed necessary, for cases such as dense breasts or for further evaluation of suspected mammographic abnormalities.

A stratified random sample was ascertained from women aged 50-60 at the time of their first invitation at the MBSP who were registered on the MBSP database and who had no personal history of $\mathrm{BC}$. The original study recruited a sample size of 404 women (i.e. 243 attendees and 161 non-attendees) in order to achieve a 95\% confidence level and 5\% confidence interval, which the present study used.

For those invited to the MBSP, attendance or nonattendance was verified through screening records but further mammography performed in private practices was self-reported. Participants were assured that their participation was voluntary and that they could withdraw from the study at any time without the need to give a reason. Information was provided to the women on how the researcher would protect their anonymity and confidentiality through coding. Prior to the commencement of the survey, participants were informed that the study was aimed at improving the understanding of women's beliefs, attitudes and perceptions on and concerns about BS and BC. Moreover, they were notified that the study had been granted ethical approval by the School Research Ethics Committee at the University of Stirling (SREC14/15-Paper No.18v4) and by the Maltese Health Ethics Committee (HEC 02/
2015). As approved by the ethics committees and following standard practice when conducting surveys by telephone [29-31], a research assistant was responsible for participant recruitment, which was carried out manually over the phone (through "yes" or "no" response options), using paper format to record verbal informed consent. Following the latter method, an appointment was scheduled by the research assistant to match its suitability for each of the participants and the primary investigator (DM). The survey was completed in a median of $25 \mathrm{~min}$ (range, 15-45 $\mathrm{min}$ ) and was carried out in one telephone call.

\section{Survey development}

The survey questionnaire consisted of standardized socio-demographic and health status questions as well as validated scales (CHBMS-MS and IPQ-R) [32, 33]. All measures were translated from English to Maltese using a back-translation procedure. A pre-test $(n=15)$ of the 121-item tool (entitled the Maltese Breast Screening Questionnaire - MBSQ) confirmed the comprehensibility, accuracy and feasibility of the questionnaire and to ensure understanding of scale items in both Maltese and English. The methods used have been published elsewhere $[19,34]$.

The survey questionnaire is composed of four sections, as follows:

1) Socio-demographic factors and health status were measured through 11 subscales (20 items),

2) Lifetime mammography practices and knowledge of mammography frequency were measured through 4 subscales (17 items),

3) Health beliefs were measured through 5 subscales (36 items),

4) Illness perceptions were measured through 7 subscales (48 items).

Response options were "yes", "no" or a series of tick boxes for socio-demographic factors and health status variables. Open questions were designed to encourage a more detailed and meaningful answer using the participant's own knowledge and/or feelings. Most of the response options for lifetime mammography practices and knowledge on mammography time intervals were mostly designed to elicit "yes", "no" or "unsure" answers, whereas closed questions were possible through a series of tick boxes. All items for health beliefs and illness perceptions had 5 response options ( $1=$ 'strongly disagree' to $5=$ 'strongly agree').

\section{Classification of variables}

Women were asked if they ever had a mammogram in their lifetime with a yes/no response. Women were categorized as 
LIFETIME ATTENDEES if they had ever had a mammogram in their lifetime or LIFETIME NON-ATTENDEES if they had never attended for a mammogram during their lifetime. Socio-demographic and health status variables (some of which were confirmed from women's health records from the screening database), as well as knowledge of screening frequency, health beliefs and illness perception variables were collected from the survey administered retrospectively from the time of the first screening invitation at the MBSP.

\section{Statistical analysis}

The chi-square test was used for comparison of proportions between two categorical variables. The Shapiro Wilk test was applied on the 14 constructs in order to determine whether these variables are normally distributed. It was found that only the variable Causes of $\mathrm{BC}$ was normally distributed. Hence, parametric tests were used for this latter construct. All the other 13 constructs were found to be not normally distributed ( $p$-value $<0.001)$ and hence, non-parametric tests were used for all the 13 constructs. When comparing two independent samples, the Independent Samples t-test was used for normally distributed data (parametric test) and Mann-Whitney test was used for the non-normal distributed dataset (nonparametric test). Similarly, for analysis including two of more independent samples, ANOVA was used for normally distributed data and Kruskal-Wallis test was used for the non-normal distributed datasets. Different variables and constructs were incorporated into six logistic regression models and the 'backward-elimination' method was applied to each model to identify the significant predictors of lifetime mammography use. The results of the regression are reported with 95\% confidence intervals, Beta (unstandardized) coefficients, Standard Errors (SE), Walds, Odds Ratios (OR) and $p$-values. All tests were analysed with an $\alpha=0.05$ level of significance; hence, any statistical test obtaining a p-value of $<0.05$ was considered as statistically significant. Missing data was minimal $(n=$ 23 for frequency of GP visit) and this missing data was reported in our previous paper [19]. Missing data was reported as is; hence this data was not excluded. The data was analyzed using SPSS version 21.

\section{Results}

\section{Sample characteristics}

Most participants $(86.9 \%)$ were married $(n=351)$. The majority $(77 \%)$ of participants were housewives $(n=311), 75.7 \%$ had a secondary level of education $(n=306)$ and more than half $(60.3 \%, n=244)$ were from below average annual income families (lower than $€ 16,113)$. Descriptive statistics are presented in our previous paper [19].

\section{Mammography screening practices}

Mammography screening practices are presented in Fig. 1. Breast screening use (LIFETIME ATTENDEES) was reported by $86.1 \%$ of women $(n=348)$, of which 243 women underwent a mammogram at the MBSP. From those who did not undergo a mammogram at the MBSP $(n=161), 105$ women underwent mammography elsewhere. No mammography was reported by $13.9 \%$ $(n=56)$ (LIFETIME NON-ATTENDEES).

\section{LIFETIME ATTENDEES versus LIFETIME NON-ATTENDEES subgroup analyses}

Chi-square tests were performed to explore associations between lifetime attendees and non-attendees, and the following variables: sociodemographic factors, health status, knowledge, health beliefs and illness perceptions.

\section{Sociodemographic factors and health status}

There was significant association between marital status and lifetime mammography $(\chi 2=9.0, p=0.030)$ such that a lower number of widowers attended for mammography (66.7\%) when compared to women of other statuses (single, married, separated/divorced) ( $\geq 87 \%)$. The higher their family income, the more likely it is for a woman to undergo mammography in her lifetime ( $x 2$ $=13.1, p=0.011)$. In fact, all women who had a family annual income greater than $€ 23,564$ claimed that they acquired mammography during their lifetime while from those with a family annual income lower than $€ 10,737$, around one in every four women did not undergo mammography. In addition, those who do not drive are more likely not to attend for a mammogram $\left(\chi^{2}=7.7, p=\right.$ 0.006). Our data showed that $91.5 \%$ of drivers attended for a mammogram in their lifetime as compared to $81.9 \%$ of non-drivers. All women in our sample with a breast condition or disease attended for mammography in their lifetime when compared to $82.9 \%$ of women without a breast condition $\left(\chi^{2}=14.2, p<0.001\right)$. Moreover, those who had relatives or close friends with cancer were more likely to attend for mammography $(\chi 2=8.3$, $p=0.016$ ).

No significant association was found between lifetime mammography and age (Independent samples t-test: $p=0.133)$, district $(\mathrm{x} 2=7.8, p=0.802)$, owning a car $\left(\mathrm{X}^{2}\right.$ $=1.2, p=0.267)$ or having an illness $\left(\mathrm{x}^{2}=0.1, p=0.709\right)$. Although there was no significant association for level of education $\left(\mathrm{X}^{2}=5.4, p=0.067\right)$ and occupation $(\mathrm{x} 2=5.7$, $p=0.057$ ), women with a higher education level and who were employed were more likely to undergo mammography in their lifetime (e.g. 93.2\% \{employed\} versus $83.9 \%$ (housewives\}). There was no significant association between having a family physician and lifetime mammography $\left(\chi^{2}=3.5, p=0.060\right)$. However, women who were not encouraged by their GP were 


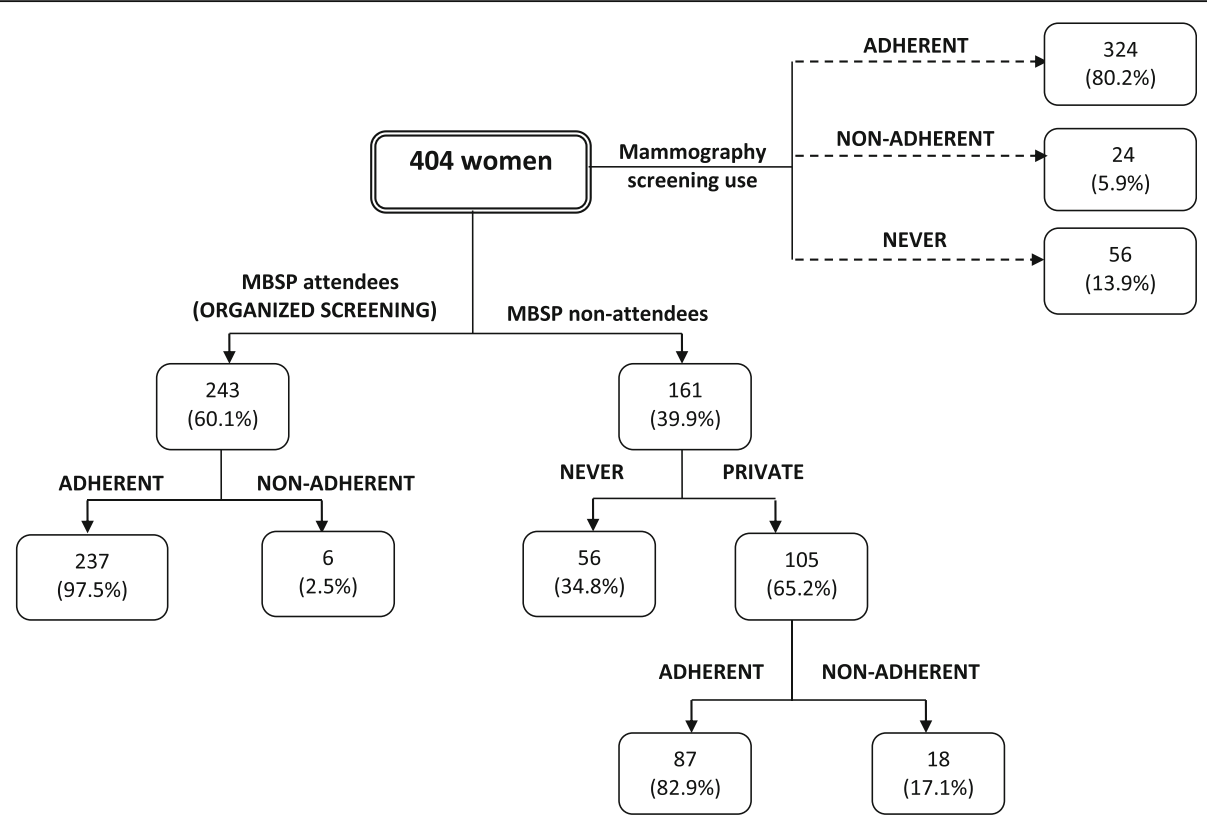

Fig. 1 Mammography use in Malta

more likely not to attend for a mammogram during their lifetime $\left(\chi^{2}=4.9, p=0.027\right)$.

Knowledge of the recommended mammography frequency Knowledge of mammography frequency was significantly associated with whether women had undergone a mammogram in their lifetime $\left(\chi^{2}=28.5, p<0.001\right)$. The main difference arises with those who said they were 'unsure' about the recommended mammography frequency (48\% of the latter group did not undergo a mammogram in their lifetime), whereas for women who mentioned other mammography frequency options (i.e. 'every year'; 'every 1.5 years'; 'every 2-3 years'), more than $86 \%$ of women from each individual latter groups had acquired a mammogram.

\section{Health beliefs}

All sub-scale items for perceived barriers and cues to action for mammography use were found to be statistically significant $(p<0.05)$ (Table 1$)$. Women tend to attend less for mammography if they are in agreement with or are undecided on the following: having a mammogram 'would make you more anxious', 'more worried,' 'more fearful about BC' and 'the procedure itself', is 'embarrassing' and 'time-consuming' and 'causes unnecessary radiation', have 'fear or distrust the medical team,' 'consider other problems in life to be greater' and feel they are 'not old enough to have a mammogram periodically' ( $p<0.001$ respectively). Significant association is mirrored for the statement 'you fear having a mammogram because you know someone (family or friend) with breast cancer' ( $p<0.001)$. When comparing pain and discomfort with mammography use, statistical significance is mirrored $(p<0.001)$, whereby the absolute majority of the undecided group (95.8\%) do not attend for a mammogram in their lifetime whereas those who are in disagreement or in agreement $(\geq 88 \%)$ attend for mammography.

Those who underwent mammography tend to attend more for mammography if advised by their GP $\left(x^{2}=\right.$ $54.4, p<0.001)$ or by relatives or friends $\left(X^{2}=16.9, p=\right.$ 0.001 ). Those who are in disagreement that hearing about $\mathrm{BC}$ and $\mathrm{BS}$ in the media would trigger thoughts to get a mammogram tend to attend less. The absolute majority of those who are in disagreement that cues to action (such as 'reminder letters', 'reminder phone calls' or 'text messages') are effective, are more likely not to attend for mammography. There is also similar significant association for the vast majority of selfefficacy sub-scale items $(p<0.001)$ i.e. for attendees, the stronger is women's confidence in arranging other things in their life to get a mammogram, while for the undecided group and those who are in disagreement with self-efficacy items are more likely not to attend for mammography screening.

\section{Illness perceptions}

There is significant association for the emotional representation subscale items $(p<0.05)$ (Table 2). For lifetime non-attendees, the higher is their anxiety $\left(\mathrm{X}^{2}=\right.$ $8.3, p=0.040)$ and fear $\left(\mathrm{X}^{2}=8.3, p=0.039\right)$ of $\mathrm{BC}$. The undecided group attend less for mammography when 
Table 1 Health Belief items

\begin{tabular}{|c|c|c|}
\hline \multirow[b]{2}{*}{ Health Beliefs } & \multicolumn{2}{|c|}{$\begin{array}{l}\text { LIFETIME SCREENERS } \\
\text { versUS } \\
\text { NON-SCREENERS }\end{array}$} \\
\hline & $x^{2}$ & $p$-value \\
\hline $\begin{array}{l}\text { There is no possibility of getting } \\
\text { breast cancer }(r)\end{array}$ & 8.4 & 0.077 \\
\hline $\begin{array}{l}\text { Your chances of getting breast } \\
\text { cancer are high }\end{array}$ & 8.2 & 0.085 \\
\hline $\begin{array}{l}\text { There may be the possibility of } \\
\text { developing breast cancer in your lifetime }\end{array}$ & 3.0 & 0.390 \\
\hline $\begin{array}{l}\text { When you get a mammogram, you } \\
\text { feel good about yourself }\end{array}$ & 45.5 & $<0.001^{*}$ \\
\hline $\begin{array}{l}\text { When you get a mammogram, you } \\
\text { do not worry as much about breast cancer }\end{array}$ & 6.4 & 0.093 \\
\hline $\begin{array}{l}\text { Having a mammogram will help you find } \\
\text { lumps early in your breasts }\end{array}$ & 19.1 & $<0.001^{*}$ \\
\hline $\begin{array}{l}\text { If you find a lump through a mammogram, } \\
\text { the treatment for breast cancer may not be } \\
\text { as bad }\end{array}$ & 5.2 & 0.160 \\
\hline $\begin{array}{l}\text { Having a mammogram will decrease your } \\
\text { chances of dying from breast cancer }\end{array}$ & 7.5 & 0.580 \\
\hline $\begin{array}{l}\text { Having a mammogram will help you find } \\
\text { a lump before it can be felt by yourself or } \\
\text { a health professional }\end{array}$ & 7.2 & 0.065 \\
\hline $\begin{array}{l}\text { Having a routine mammogram would } \\
\text { make you anxious about breast cancer }\end{array}$ & 27.7 & $<0.001^{*}$ \\
\hline $\begin{array}{l}\text { Having a routine mammogram would } \\
\text { make you worry }\end{array}$ & 22.8 & $<0.001^{*}$ \\
\hline $\begin{array}{l}\text { You fear having a mammogram because } \\
\text { you might find out that something is wrong }\end{array}$ & 39.7 & $<0.001^{*}$ \\
\hline $\begin{array}{l}\text { You fear having a mammogram because } \\
\text { you do not know the procedure or what } \\
\text { to expect }\end{array}$ & 145.8 & $<0.001^{*}$ \\
\hline $\begin{array}{l}\text { You fear having a mammogram because } \\
\text { you know someone (family or friend) with } \\
\text { breast cancer }\end{array}$ & 20.0 & $<0.001^{*}$ \\
\hline $\begin{array}{l}\text { It is embarrassing for you to have a } \\
\text { mammogram }\end{array}$ & 40.4 & $<0.001^{*}$ \\
\hline $\begin{array}{l}\text { Undergoing mammography will be } \\
\text { painful or uncomfortable }\end{array}$ & 147.5 & $<0.001^{*}$ \\
\hline Having a mammogram is time consuming & 31.1 & $<0.001^{*}$ \\
\hline $\begin{array}{l}\text { You are discontent with Breast Screening } \\
\text { personnel as they have been rude to you }\end{array}$ & $n / a$ & $\mathrm{n} / \mathrm{a}$ \\
\hline You have fear or distrust in the medical team & 32.9 & $<0.001^{*}$ \\
\hline $\begin{array}{l}\text { Having a mammogram would expose you } \\
\text { to unnecessary radiation }\end{array}$ & 27.9 & $<0.001^{*}$ \\
\hline $\begin{array}{l}\text { You have too many other problems in your } \\
\text { life than to get a mammogram done }\end{array}$ & 83.1 & $<0.001^{*}$ \\
\hline $\begin{array}{l}\text { You are not old enough to have a } \\
\text { mammogram periodically }\end{array}$ & 35.4 & $<0.001^{*}$ \\
\hline $\begin{array}{l}\text { If your GP advises you to attend for a } \\
\text { mammogram, you will attend }\end{array}$ & 54.4 & $<0.001^{*}$ \\
\hline $\begin{array}{l}\text { If your relatives or friends advise you to } \\
\text { attend for a mammogram, you will attend }\end{array}$ & 16.9 & $0.001^{*}$ \\
\hline
\end{tabular}

Table 1 Health Belief items (Continued)

\begin{tabular}{|c|c|c|}
\hline \multirow[b]{2}{*}{ Health Beliefs } & \multicolumn{2}{|c|}{$\begin{array}{l}\text { LIFETIME SCREENERS } \\
\text { versUS } \\
\text { NON-SCREENERS }\end{array}$} \\
\hline & $x^{2}$ & $p$-value \\
\hline $\begin{array}{l}\text { If someone close to you has been } \\
\text { diagnosed with breast cancer, you will } \\
\text { attend for a mammogram }\end{array}$ & 39.4 & $<0.001^{*}$ \\
\hline $\begin{array}{l}\text { Hearing about breast cancer and breast } \\
\text { screening in the media or news makes } \\
\text { you think about getting a mammogram }\end{array}$ & 34.2 & $<0.001^{*}$ \\
\hline $\begin{array}{l}\text { Reminder letters would help you to get } \\
\text { a mammogram }\end{array}$ & 38.9 & $<0.001^{*}$ \\
\hline $\begin{array}{l}\text { Reminder phone calls or text messages } \\
\text { would help you to get a mammogram }\end{array}$ & 38.9 & $<0.001^{*}$ \\
\hline $\begin{array}{l}\text { Routine educational talks regarding } \\
\text { breast cancer awareness would help } \\
\text { you to get a mammogram }\end{array}$ & 37.1 & $<0.001^{*}$ \\
\hline $\begin{array}{l}\text { You feel confident that if you had a } \\
\text { mammogram done, any abnormalities } \\
\text { in your breasts will be detected }\end{array}$ & 0.6 & 0.960 \\
\hline $\begin{array}{l}\text { You can arrange other things in your life } \\
\text { to get a mammogram }\end{array}$ & 49.2 & $<0.001^{*}$ \\
\hline $\begin{array}{l}\text { In case you need a mammogram, you will } \\
\text { find a place to get it done }\end{array}$ & 32.8 & $<0.001^{*}$ \\
\hline $\begin{array}{l}\text { You can make an appointment for } \\
\text { a mammogram }\end{array}$ & 36.0 & $<0.001^{*}$ \\
\hline $\begin{array}{l}\text { You can arrange transportation to get } \\
\text { a mammogram }\end{array}$ & 41.1 & $<0.001^{*}$ \\
\hline $\begin{array}{l}\text { You can talk to people at the breast } \\
\text { screening centre about your concerns }\end{array}$ & $\mathrm{n} / \mathrm{a}$ & $\mathrm{n} / \mathrm{a}$ \\
\hline $\begin{array}{l}\text { You can find a way to pay for a mammogram } \\
\text { if you need to }\end{array}$ & 32.3 & $<0.001^{*}$ \\
\hline
\end{tabular}

*Statistically significant

$(r)=$ reverse scored

${ }^{a}$ Chi-square test was applied for all health beliefs; hence the categorical answers were used to apply this test for association. For each question, respondents were asked to select a number between 1 and 5, where $1=$ strongly disagree and $5=$ strongly agree. For certain items, responses were regrouped to ensure the feasibility of the Chi-square test

taking into account that their emotional state $\left(\mathrm{x}^{2}=12.9\right.$, $p=0.002)$ and their own behaviour $\left(\mathrm{x}^{2}=12.7, p=0.002\right)$ is perceived to possibly cause $\mathrm{BC}$. Those who agree that $\mathrm{BC}$ can be caused by their own behaviour $\left(\chi^{2}=12.7\right.$, $p=0.002)$ or by a germ/virus $(\chi 2=9.4, p=0.009)$ attend less for mammography, while those who consider $\mathrm{BC}$ to have major consequences in life $\left(x^{2}=9.9, p=0.019\right)$ attend more.

\section{Health beliefs and illness perception constructs}

The following $4 \mathrm{HBM}$ and 1 CSM constructs were found to be significantly different when comparing lifetime mammography attenders and non-attenders: perceived benefits, perceived barriers, cues to action, self-efficacy $(p<0.001$ respectively) and emotional representations $(p=0.033)$ (Table 3$)$. 
Table 2 Illness Perception items

\begin{tabular}{|c|c|c|}
\hline \multirow[b]{2}{*}{ IIIness Perceptions } & \multicolumn{2}{|c|}{$\begin{array}{l}\text { LIFETIME } \\
\text { SCREENERS } \\
\text { versus } \\
\text { NON-SCREENERS }\end{array}$} \\
\hline & $x^{2}$ & $p$-value \\
\hline $\begin{array}{l}\text { The presence of a lump or thickening } \\
\text { in the breast }\end{array}$ & 1.8 & 0.611 \\
\hline Nipple discharge & 2.3 & 0.509 \\
\hline Sudden nipple retraction & 1.1 & 0.769 \\
\hline $\begin{array}{l}\text { Change in shape or appearance of } \\
\text { the nipple }\end{array}$ & 1.2 & 0.743 \\
\hline $\begin{array}{l}\text { Breast swelling, dimpling, redness or } \\
\text { soreness of the skin }\end{array}$ & 0.9 & 0.826 \\
\hline Skin changes of the breast & 1.7 & 0.641 \\
\hline A sudden change in breast size & 1.5 & 0.688 \\
\hline Aching breasts & 1.5 & 0.820 \\
\hline Stress or worry & 3.0 & 0.223 \\
\hline $\begin{array}{l}\text { Your mental attitude (e.g. thinking } \\
\text { about life negatively) }\end{array}$ & 2.0 & 0.580 \\
\hline Family problems or worries & 2.9 & 0.233 \\
\hline Overwork & 7.9 & 0.052 \\
\hline $\begin{array}{l}\text { Your emotional state (e.g. feeling down, } \\
\text { lonely, anxious, empty) }\end{array}$ & 12.9 & $0.002^{*}$ \\
\hline Your personality & 3.0 & 0.391 \\
\hline Hereditary - it runs in the family & 9.7 & $0.021^{*}$ \\
\hline Diet or eating habits & 1.5 & 0.679 \\
\hline Poor medical care in the past & 0.8 & 0.847 \\
\hline Your own behaviour & 12.7 & $0.002^{*}$ \\
\hline Ageing & 1.9 & 0.395 \\
\hline Smoking & 1.8 & 0.601 \\
\hline Alcohol & 1.2 & 0.538 \\
\hline A germ or virus & 9.4 & $0.009^{*}$ \\
\hline Pollution in the environment & 1.4 & 0.709 \\
\hline Altered immunity & 2.5 & 0.469 \\
\hline Chance or bad luck & 3.0 & 0.562 \\
\hline Accident or injury & 3.6 & 0.460 \\
\hline Breast cancer will last a short time & 5.8 & 0.120 \\
\hline $\begin{array}{l}\text { Breast cancer is likely to be permanent } \\
\text { rather than temporary }\end{array}$ & 0.9 & 0.650 \\
\hline $\begin{array}{l}\text { A patient with breast cancer goes } \\
\text { through cycles in which her illness } \\
\text { gets better and worse }\end{array}$ & 5.8 & 0.215 \\
\hline $\begin{array}{l}\text { Breast cancer has major consequences } \\
\text { on a patient's life }\end{array}$ & 9.9 & $0.019^{*}$ \\
\hline $\begin{array}{l}\text { Breast cancer will not have much effect } \\
\text { on your life }\end{array}$ & 6.1 & 0.189 \\
\hline $\begin{array}{l}\text { Breast cancer would strongly affect the } \\
\text { way others see you }\end{array}$ & 7.8 & 0.100 \\
\hline Breast cancer has serious economic & 5.0 & 0.174 \\
\hline
\end{tabular}

Table 2 Illness Perception items (Continued)

\begin{tabular}{|c|c|c|}
\hline \multirow[b]{2}{*}{ IIIness Perceptions } & \multicolumn{2}{|c|}{$\begin{array}{l}\text { LIFETIME } \\
\text { SCREENERS } \\
\text { versus } \\
\text { NON-SCREENERS }\end{array}$} \\
\hline & $x^{2}$ & $p$-value \\
\hline $\begin{array}{l}\text { Breast cancer would strongly affect the way you see } \\
\text { yourself as a person }\end{array}$ & 0.9 & 0.826 \\
\hline $\begin{array}{l}\text { Breast cancer would threaten a relationship with your } \\
\text { husband or partner }\end{array}$ & 2.5 & 0.641 \\
\hline $\begin{array}{l}\text { If you had breast cancer, your whole life } \\
\text { would change }\end{array}$ & 5.6 & 0.133 \\
\hline $\begin{array}{l}\text { If you developed breast cancer, the chances } \\
\text { of living a long life would decrease }\end{array}$ & 4.9 & 0.179 \\
\hline $\begin{array}{l}\text { There is a lot which you can do to control } \\
\text { the symptoms if Breast Cancer occurs }\end{array}$ & 0.7 & 0.948 \\
\hline $\begin{array}{l}\text { The course of Breast Cancer will depend } \\
\text { on your actions }\end{array}$ & 2.9 & 0.400 \\
\hline $\begin{array}{l}\text { Your actions will have an effect on the } \\
\text { outcome of Breast Cancer }\end{array}$ & 4.0 & 0.261 \\
\hline $\begin{array}{l}\text { There is no treatment that will help to } \\
\text { improve Breast Cancer }\end{array}$ & 4.0 & 0.400 \\
\hline $\begin{array}{l}\text { The treatment provided will be effective } \\
\text { in controlling or curing Breast Cancer }\end{array}$ & 3.1 & 0.371 \\
\hline $\begin{array}{l}\text { The negative effects of Breast Cancer can be } \\
\text { prevented or avoided by the treatment given }\end{array}$ & 1.5 & 0.822 \\
\hline $\begin{array}{l}\text { You have a clear picture and understanding } \\
\text { of Breast Cancer }\end{array}$ & 4.5 & 0.211 \\
\hline Breast Cancer is a mystery to you & 2.1 & 0.720 \\
\hline $\begin{array}{l}\text { You get anxious when you think about } \\
\text { Breast Cancer }\end{array}$ & 8.3 & $0.040^{*}$ \\
\hline Breast Cancer makes you feel afraid & 8.3 & $0.039^{*}$ \\
\hline $\begin{array}{l}\text { You get worried when you think about } \\
\text { Breast Cancer }\end{array}$ & 4.3 & 0.231 \\
\hline
\end{tabular}

*Statistically significant

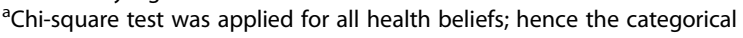
answers were used to apply this test for association. For each question, respondents were asked to select a number between 1 and 5 , where $1=$ strongly disagree and $5=$ strongly agree. For certain items, responses were regrouped to ensure the feasibility of the Chi-square test

The findings show that for women who acquire mammography during their lifetime, the higher is their agreement on perceived benefits to mammography uptake, while more cues to action and greater selfefficacy help women to undergo mammography. Higher perceived barriers to mammography screening and stronger emotional representations of $\mathrm{BC}$ are associated with no mammography use during a woman's lifetime.

\section{Predictors of mammography screening practices}

We further explored which variables and constructs were most significant to women's attendance (LIFETIME ATTENDEES versus LIFETIME NON-ATTENDEES). A number of logistic regression models were applied (Table 4) in order to examine the variables/constructs (independent variables) which are key to identifying 
Table 3 Comparisons between mammography screening use and health beliefs/illness perception constructs. For all constructs, Mann Whitney test and Independent Samples t-test were applied to compare 'LIFETIME ATTENDEES' and 'LIFETIME NON-ATTENDEES'

\begin{tabular}{|c|c|c|c|c|}
\hline & $\begin{array}{l}\text { LIFETIME ATTENDEES } \\
(n=348)\end{array}$ & $\begin{array}{l}\text { LIFETIME NON-ATTENDEES } \\
(n=56)\end{array}$ & Test Statistic & $p$-value \\
\hline Perceived Susceptibility & $M=9.6, S D=1.0$ & $M=9.6, S D=1.0$ & $10,065.5^{a}$ & 0.669 \\
\hline Perceived Benefits & $M=24.0, S D=1.8$ & $M=23.1, S D=1.5$ & $6816.5^{\mathrm{a}}$ & $<0.001^{*}$ \\
\hline Perceived Barriers & $M=27.5, S D=4.9$ & $M=34.8, S D=4.9$ & $16,569.5^{\mathrm{a}}$ & $<0.001^{*}$ \\
\hline Cues to action & $M=27.3, S D=3.2$ & $M=23.1, S D=4.8$ & $4306.0^{\mathrm{a}}$ & $<0.001^{*}$ \\
\hline Self-Efficacy & $M=24.8, S D=2.7$ & $M=22.7, S D=2.8$ & $6114.5^{\mathrm{a}}$ & $<0.001^{*}$ \\
\hline Breast Cancer Identity & $M=30.6, S D=2.3$ & $M=30.7, S D=2.0$ & $10,344.0^{\mathrm{a}}$ & 0.434 \\
\hline Causes of Breast Cancer & $M=56.0, S D=7.2$ & $M=57.4, S D=6.9$ & $-1.3^{b}$ & 0.186 \\
\hline Cancer Timeline: Acute/Chronic & $M=6.1, S D=0.9$ & $M=6.2, S D=0.9$ & $10,213.5^{\mathrm{a}}$ & 0.534 \\
\hline Cancer Timeline: Cyclical & $M=3.6, S D=0.7$ & $M=3.4, S D=0.7$ & $8513.0^{\mathrm{a}}$ & 0.069 \\
\hline Consequences & $M=28.2, S D=2.5$ & $M=28.5, S D=2.0$ & $9909.0^{\mathrm{a}}$ & 0.837 \\
\hline Personal Control & $M=11.8, S D=0.8$ & $M=11.9, S D=0.5$ & $9890.0^{\mathrm{a}}$ & 0.757 \\
\hline Treatment Control & $M=9.9, S D=0.7$ & $M=10.0, S D=0.5$ & $10,592.0^{\mathrm{a}}$ & 0.119 \\
\hline Illness Coherence & $M=7.0, S D=1.1$ & $M=7.0, S D=1.1$ & $9857.5^{\mathrm{a}}$ & 0.880 \\
\hline Emotional Representations & $M=12.2, S D=2.1$ & $M=12.7, S D=2.5$ & $11,431.5^{\mathrm{a}}$ & $0.033^{*}$ \\
\hline
\end{tabular}

*Statistically significant, ${ }^{a}$ Mann Whitney test, ${ }^{\mathrm{b}}$ Independent Samples t-test

differences between women who attended mammography during lifetime and non-attendees (dependent variables). Model 1 represents the demographics against attendance/non-attendance. Although 'drive' and 'status' variables were found to be significant $(p<0.05)$, this model was not found to provide any accuracy to predict non-attendance. Hence, demographics are not providing any useful prediction for the scope of this analysis. Model 2 focused on Health Belief variables only, which served as the independent variables for this model. This model predicted attendance with an accuracy of $98.3 \%$ and non-attendance with an accuracy of $48.2 \%$. Five variables were found to be significant $(p<0.05)$ with an Odds Ratio (OR) that varies between 0.213 (fear of unknown procedure) and 3.327 (arrange transportation) for all the five variables. Model 3 focused on Illness Perception variables only, which served as the independent variables for this model. This model predicted attendance with an accuracy of $99.4 \%$ and nonattendance with an accuracy of $5.4 \%$. Six variables were found to be significant $(p<0.05)$ with OR varying between 0.432 (fear of breast cancer) and 1.926 (major consequences in life). The above significant predictors from both models 2 and 3 were incorporated into a new single model (Model 4), both health beliefs and illness perception variables serving as the independent variables for this model. The model accuracy, when combining both scores, improved to $98.0 \%$ for attendance and $53.6 \%$ for non-attendance. The model retained six significant predictors $(p<0.05)$ with OR varying between 0.212 (fear of unknown procedure) and 3.202 (arrange transportation). When all individual Health
Belief and Illness Perception items were incorporated into one model (Model 5), eight variables were found to be significantly different $(p<0.05)$ with OR varying between 0.149 (fear of unknown procedure) and 3.716 (arrange transportation). The accuracy of the model improved again to $97.1 \%$ for attendees and $58.9 \%$ accuracy for non-attendees. When the 14 constructs (not individual items) related to Health Beliefs and Illness Perceptions were used to construct a logistic regression model (Model 6), 'perceived barriers' (OR 0.776) and 'cues to action' (OR 1.196) were found to be the strongest and most significant predictors $(\mathrm{p}<0.05)$ to describe the variance between the subgroups. However, the accuracy for predicting the non-attendees was found to be $37.5 \%$ and $96.6 \%$ for predicting attendance, which is inferior when compared to Model 4. No health status variables were found to be significant and were therefore not included in Table 4.

\section{Discussion}

The extant research identifies multifactorial reasons why women choose not to attend for mammography screening $[9,35-39]$, particularly psychological, socio-economic and practical factors $[15,28,40,41]$. Hence, this study was carried out to provide an understanding of the determinants of lifetime mammography use among Maltese women who attend 'anywhere' and those who 'never' attend for mammography. This study found that four health belief constructs (perceived benefits, perceived barriers, cues to action, self-efficacy) and one illness perception construct (emotional representations) influence lifetime mammography screening practices among 
Table 4 Logistic Regression Models on lifetime mammography use (LIFETIME ATTENDEES versus LIFETIME NON-ATTENDEES) against different variables and different constructs

\begin{tabular}{|c|c|c|c|c|c|c|c|c|}
\hline & B & SE & Wald & $P$-value & OR & $95 \% \mathrm{Cl}$ & $\begin{array}{l}\text { Model Accuracy } \\
\text { Attendance }\end{array}$ & $\begin{array}{l}\text { Model Accuracy Non } \\
\text { attendance }\end{array}$ \\
\hline Model 1: Demographics & & & & & & & $100 \%$ & $0 \%$ \\
\hline Drive & 0.912 & 0.325 & 7.891 & 0.005 & 2.488 & $1.317,4.700$ & & \\
\hline Status & 0.591 & 0.224 & 6.987 & 0.008 & 1.807 & $1.165,2.801$ & & \\
\hline Constant & -4.605 & 0.792 & 33.773 & 0.000 & 0.010 & & & \\
\hline Model 2: Health Beliefs & & & & & & & $98.3 \%$ & $48.2 \%$ \\
\hline Fear of unknown procedure & -1.548 & 0.219 & 50.028 & 0.000 & 0.213 & $0.138,0.327$ & & \\
\hline Other life problems & -1.213 & 0.302 & 16.130 & 0.000 & 0.297 & $0.165,0.537$ & & \\
\hline Relative or close friend with breast cancer & 0.383 & 0.187 & 4.218 & 0.040 & 1.467 & $1.018,2.114$ & & \\
\hline Reminder letters & 1.099 & 0.307 & 12.826 & 0.000 & 3.001 & $1.645,5.475$ & & \\
\hline Arrange Transportation & 1.202 & 0.410 & 8.605 & 0.003 & 3.327 & $1.490,7.427$ & & \\
\hline Constant & -1.993 & 2.109 & 0.893 & 0.345 & 0.136 & & & \\
\hline Model 3: Illness Perceptions & & & & & & & $99.4 \%$ & $5.4 \%$ \\
\hline Hereditary & 0.579 & 0.233 & 6.179 & 0.013 & 1.784 & $1.130,2.816$ & & \\
\hline Own behaviour & -0.554 & 0.213 & 6.774 & 0.009 & 0.575 & $0.379,0.872$ & & \\
\hline Major consequences in life & 0.655 & 0.255 & 6.627 & 0.010 & 1.926 & $1.169,3.172$ & & \\
\hline Economic consequences & 0.520 & 0.238 & 4.777 & 0.029 & 1.683 & $1.055,2.683$ & & \\
\hline Threatens your relationship & -0.396 & 0.178 & 4.973 & 0.026 & 0.673 & $0.475,0.953$ & & \\
\hline Fear of breast cancer & -0.840 & 0.280 & 9.038 & 0.003 & 0.432 & $0.250,0.746$ & & \\
\hline Constant & 1.060 & 1.828 & 0.337 & 0.562 & 2.888 & & & \\
\hline Model 4: Health Beliefs and IIIness Perceptions & & & & & & & $98.0 \%$ & $53.6 \%$ \\
\hline Fear of unknown procedure & -1.553 & 0.224 & 48.123 & 0.000 & 0.212 & $0.136,0.328$ & & \\
\hline Other life problems & -1.239 & 0.310 & 15.973 & 0.000 & 0.290 & $0.158,0.532$ & & \\
\hline Relative or close friend with breast cancer & 0.407 & 0.189 & 4.618 & 0.032 & 1.502 & $1.036,2.178$ & & \\
\hline Reminder letters & 1.123 & 0.316 & 12.638 & 0.000 & 3.074 & $1.655,5.710$ & & \\
\hline Arrange transportation & 1.164 & 0.411 & 8.028 & 0.005 & 3.202 & $1.432,7.163$ & & \\
\hline Own behaviour & -0.612 & 0.288 & 4.536 & 0.033 & 0.542 & $0.309,0.952$ & & \\
\hline Constant & -0.240 & 2.306 & 0.011 & 0.917 & 0.787 & & & \\
\hline Model 5: Health Beliefs and IIIness Perceptions & & & & & & & $97.1 \%$ & $58.9 \%$ \\
\hline Poor medical care & 0.878 & 0.360 & 5.970 & 0.015 & 2.407 & $1.190,4.870$ & & \\
\hline Own behaviour & -1.195 & 0.380 & 9.893 & 0.002 & 0.303 & $0.144,0.637$ & & \\
\hline Pollution & 0.603 & 0.283 & 4.543 & 0.033 & 1.829 & $1.050,3.185$ & & \\
\hline Possibility of developing breast cancer & -1.295 & 0.658 & 3.876 & 0.049 & 0.274 & $0.075,0.994$ & & \\
\hline Fear of unknown procedure & -1.907 & 0.268 & 50.587 & 0.000 & 0.149 & $0.088,0.251$ & & \\
\hline Other life problems & -1.478 & 0.331 & 19.976 & 0.000 & 0.228 & $0.119,0.436$ & & \\
\hline Reminder letters & 1.256 & 0.321 & 15.352 & 0.000 & 3.512 & $1.874,6.584$ & & \\
\hline Arrange transportation & 1.313 & 0.442 & 8.832 & 0.003 & 3.716 & $1.564,8.831$ & & \\
\hline Constant & 3.476 & 3.406 & 1.041 & 0.308 & 32.328 & & & \\
\hline Model 6: The 14 constructs & & & & & & & $96.6 \%$ & $37.5 \%$ \\
\hline Perceived barriers & -0.253 & 0.039 & 43.157 & 0.000 & 0.776 & $0.720,0.837$ & & \\
\hline Cues to action & 0.179 & 0.041 & 19.169 & 0.000 & 1.196 & $1.104,1.295$ & & \\
\hline Constant & 5.192 & 1.688 & 9.460 & 0.002 & 179.859 & & & \\
\hline
\end{tabular}

$B$ unstandardized coefficients; SE standard error; $O R$ odds ratio; $C l$ confidence interval 
Maltese women. In particular, our findings show that women who perceive more barriers to mammography attendance (e.g. fear of pain, fear of the result), fewer benefits (e.g. lower belief in early detection), lower cues to action (e.g. no advice by a GP) and lower self-efficacy (e.g. lower confidence in one's ability to arrange other things in life), and who have higher emotional representations of BC (e.g. greater fear, worry, anxiety and who consider other problems in life to be greater) were less likely to attend for mammography during their lifetime. This is consistent with Champion's Health Belief Model and Leventhal's Common-Sense Model of self-regulation. This also implies that women who have previously experienced mammography screening may already have established health-related behaviours [42] and have therefore already recognized the benefits of undergoing regular mammography use, have already overcome personal barriers to undergo mammography, have increased their selfconfidence in getting screened throughout their lifetime and have higher levels of health motivation [23, 28, 4244]. Therefore, efforts should be focused on identifying and encouraging attendance among women who have never participated in screening [44].

Our findings emphasize the importance of adapting interventions for women with lower socio-economic backgrounds, particularly since widowers, those having lower family incomes and non-drivers were found to be significantly associated with lifetime non-attendance in this study. These women are less likely to attend for screening anywhere. Women with socio-economic disadvantages in life are less likely to take part in any mammography screening. This relationship has been shown in previous literature [45]. Having a free-ofcharge, invitational, organized screening programme is one of many interventions which would help to increase mammography use. This socioeconomic difference is reemphasized in our previous study whereby household income has solely emerged as significantly associated with attendance to first invitation at the MBSP [19]. Although not statistically significant in this present study, women with a higher level of education and in employment were found to be more likely to attend than nonemployed women and those with a lower education level. These socio-economic characteristics may serve as a proxy for interaction with other people, and in the degree of social integration during a woman's lifetime. These findings may indirectly reflect social differences as well as the degree of equality regarding detection of $\mathrm{BC}$ and treatment received, and may help to identify prognostic factors amenable to intervention.

There were significant associations in this study between lifetime attendees and non-attendees regarding having a breast condition or $\mathrm{BC}$ in the family and the close relations, such that women with a breast condition or who had relatives or close friends with cancer were more likely to attend for mammography during their lifetime. Similarly, having a family member or close friends with BC was found to be associated with mammography attendance in other studies $[46,47]$ but contrast others [48-50]. Women most often play key roles as health managers and family caregivers [51-53] and this is not only reflected in that women more regularly than men are searching for health-related information on the Internet [54] but in women seeking a preventive action when faced with a prior personal or close relation experience that subsequently triggers them to engage in a health-related behaviour $[50,55,56]$. This corresponds with other research in other fields, particularly on mothers and children [57].

It has been acknowledged that lifetime non-attendees are an extremely difficult group to target and are a real challenge for screening management and public health officials [58]. For instance, structural and socio-economic factors such as age, income and marital status cannot be directly or easily modified [59]. Hence, although the exploration of such variables can help identify those at risk for a poor screening profile, such research offers little direction in terms of viable interventions. Therefore, in order to better understand which constructs are most significant to lifetime mammography non-attendees in Malta, our logistic regression analyses confirmed that health beliefs were the strongest and most important predictors to lifetime non-attendance and this result has been consistent across our previous research on first invitation to the MBSP [19], re-attendance [28] and adherence to timely mammography use [60]. This implies that lifetime non-attendees are women who were not motivated in health behaviour, have strong emotional representations of $\mathrm{BS}$ and $\mathrm{BC}$, who highlight more barriers to screening, lower benefits and less cues to action because this is a new skill for them. This is evidenced by women who do not attend for mammography in other countries $[59,61]$ because they perceive greater barriers to BS.

Our data shows evidence that lifetime non-attendees were less encouraged by their GP to attend for a mammogram during their lifetime. However, it is also true that Maltese women tend to visit their GPs when they have a problem rather than on a routine basis [19]. While it is known that GPs are significantly more influential than relatives or friends at supporting the uptake of BS by mammography [55], women obtain information more often from friends and relatives than from official sources [62]. This reinforces the influence of word of mouth from friends and relatives as a means of screening promotion [55], supporting related promotional schemes worldwide [63-65]. However, while word of mouth is important, such initiatives are aimed at ensuring that information passed through word of mouth is based on factual information, rather than emotional 
reasons [55]. Although physician recommendation is critical for the provision of factual information (about BS, BC and adherence recommendations) $[59,66]$, many women still do not screen frequently enough [59]. Hence, it seems increasingly clear that interventions should be developed to target variables that are both amenable to change and for which there is scope for improvement, if breast screening rates are to be improved.

Emotional representations play a central role in models of both self-regulation and health behaviour [66] as well as in models regarding the "uptake" of health-promoting messages [67]. However, research cannot determine exactly what women are afraid of or how the diverse fear components are related to one another or to screening behaviour, particularly since contradictory findings across studies make it difficult to draw conclusions from the literature. Hence, fear, anxiety and worry are often termed to encompass nearly "everything" [59]. Our current study investigated barriers related to fear more specifically and we found that fear is certainly related to a breast cancer diagnosis, fear of pain/discomfort, fear of embarrassment, fear of the medical establishment, radiation, as well as general worry and anxiety. Similarly, other research found that fear is instilled due to an awaited result that may cause a negative impact on the self and on the family [59, $61,68,69]$, due to the pain perceived or experienced during the test $[15,44,49,70,71]$, due to the sense of uncomfortableness whereby one exposes such an intimate body part in front of another person [44, 45, 71, 72], fear of the medical team $[59,73]$, fear that X-rays would cause more harm than good to the breast $[15,45]$ and nonspecific "cancer worry" $[45,49,59,74,75]$ and general anxiety $[76,77]$. Studies suggest that mammography-related anticipatory anxiety may contribute to poorer adherence $[15,69,78]$ because women may avoid undergoing mammography to reduce their anxiety. It is possible that reports of mammography-related anxiety and catastrophizing thoughts related to mammography pain reflect women's level of general anxiety $[79,80]$. This may also operate as a barrier for relatives or friends to undergo mammography or attend a particular unit [81]. Hence, such concerns need also to be taken seriously to encourage long-term adherence among attendees by finding ways how to avoid pain and maintaining client satisfaction [82, 83]. Women can be prepared for mammography by informing them about possible short-lived pain or discomfort, preferably in the invitation letter or in screening campaigns [15]. Additionally, calming self-statements or distraction techniques could be utilised to reduce the fear of pain and embarrassment during the test [23].

The undecided group of women in this study tend to attend less for mammography screening, particularly those who are unsure about: (i) self-efficacy items such as whether they can arrange other things in life to get a mammogram, (ii) screening barriers such as whether mammography is painful or uncomfortable, (iii) illness perception items such as whether one's emotional state or own behaviour causes BC, and (iv) mammography frequency recommendations). In all of our findings, limited knowledge was found to be significantly associated with attendance to the first screening invitation, reattendance, lifetime mammography use and compliance with recommended time intervals. This calls for urgent renewed health education and tailored information on the importance of screening while addressing misunderstandings, debunking screening myths and improving knowledge gaps. All of our findings in this study, and when considered in the light of our previous results, can be used to lead the development of current non-existent, evidence-based interventions in Malta.

\section{Strengths and limitations}

Our group of 'real' non-attendees came from the same target screening group, which further strengthens the value of our data. Additionally, the rich dataset allowed for diverse subgroup analyses, which facilitated an overview of lifetime screening practices, though not without possible response bias as a possible weakness. An additional strength is that the 121-item tool (MBSQ) contains information that makes it possible to adjust the analyses for potential confounders. Some aspects of study limitations should be considered. One limitation of the study is its cross-sectional design, which does not allow for the associations of non-attendance with socio-demographic factors such as age to be studied over time. Future research is needed to evaluate a potential cause effect relation. A problem in some of the analyses is the low number of 'real' non-attendees, hence a lower level of confidence in the results for this particular group. This may have led to a type I and/or type II error in relation to some of the analysed factors. Another limitation of this study is that self-reports for private mammography was used to measure lifetime mammography rather than objective data from private mammographic screening clinics. However, no national data records from private practices are currently available to date in Malta. Hence, self-reports for lifetime mammography use was the only possible method of data collection. The findings are likely to be generalizable and broadly applicable to other populations. Although limited to the Maltese population, the representation of our heterogeneous population derives from different parts of the country. However, given the potential for cultural differences, varied health care delivery systems, and socioeconomic factors between countries, the generalizability of study results may be somewhat limited. 


\section{Conclusions}

Our findings may be used to develop cognitive interventions aimed at enhancing perceived benefits, reducing perceived barriers, and modifying negative emotional representations to $\mathrm{BC}$ in order to motivate women to start undertaking mammography screening. In general, our results are in line with differences reported in the literature between screening attendees and non-attendees, such that non-attendees were less knowledgeable of the recommended mammography frequency, had attitudinal, emotional and motivational barriers, less socio-economic support and were less confident in themselves and the medical establishment. Additionally, our study showed that health beliefs were the most significant predictors to lifetime mammography screening behaviour. Hence, screening organizers and public health officials should target women's perceived barriers and enhance cues to action when reaching out to non-attendees. Further qualitative research is required to clarify the determinants and consequences of emotional barriers, particularly fear among the 'real' non-attending cohort, and also to evaluate the need for a more targeted approach among this hardest-to-reach group in order to understand the complexity of their behavioural barriers.

\begin{abstract}
Abbreviations
B: Unstandardized coefficients; BC: Breast cancer; BS: Breast screening; CHBMS-MS: Champion's health belief model scale for mammography screening; Cl: Confidence interval; CSM: Common-sense model; GP: General practitioner; HBM: Health belief model; IPQ: IIIness perception questionnaire; IPQ-R: Revised illness perception questionnaire; M: Mean score; MBSP: Maltese breast screening programme; MS: Mammography screening; OR: Odds ratio; SD: Standard deviation; SE: Standard error
\end{abstract}

\section{Acknowledgements \\ The authors would like to forward their gratitude to Prof. Victoria Champion and Prof. Rona Moss-Morris for developing the CHBMS-MS and IPQ-R scales respectively and for providing the opportunity to translate and adapt it into the Maltese culture and language. This study was developed as part of the activities of the PhD in Health offered by the University of Stirling in Scotland. We thank the National Screening Programme in Malta for providing access to the data.}

\section{Funding}

The PhD program is part-financed by the Malta Government Scholarship Scheme (MGSS), Government of Malta.

\section{Availability of data and materials}

Data supporting the conclusions of this study are included within the manuscript. The raw datasets analysed during the current study are available from the corresponding author on reasonable request.

\section{Authors' contributions}

DM conceived the study, supervised all aspects of its conduction and wrote the manuscript. VM assisted with data analysis and interpretation of data and revised the manuscript. GH assisted with the study design, and critically reviewed and revised the manuscript. All authors helped to conceptualise ideas, interpret findings and review drafts of the manuscript. All authors read and approved the final manuscript.

\section{Authors' information}

DM: BSc (Hons), MSc, PhD candidate.

VM: BSC (Hons), MSc, PhD.

$\mathrm{GH}$ : BA (Hons), MSc, PhD, Associate Professor

\section{Ethics approval and consent to participate}

Ethics approval was obtained via an application to the School Research Ethics Committee at the University of Stirling (SREC14/15-Paper No.18v4) and from the Maltese Health Ethics Committee (HEC 02/2015).

\section{Consent for publication}

Not applicable.

\section{Competing interests}

The authors declare that they have no competing interests regarding the publication of this paper.

\section{Publisher's Note}

Springer Nature remains neutral with regard to jurisdictional claims in published maps and institutional affiliations.

\section{Author details}

${ }^{1}$ Faculty of Health Sciences, University of Stirling, Room E9, Pathfoot, Stirling FK9 4LA, Scotland. ${ }^{2}$ Ministry for Health, Cancer Care Pathways Directorate, Sir Anthony Mamo Oncology Centre, Level -1, Dun Karm Psaila Street, Msida MSD 2090, Malta. ${ }^{3}$ Department of Management, University of Malta, Msida, Malta.

Received: 11 October 2017 Accepted: 17 January 2018

Published online: 25 January 2018

\section{References}

1. Ferlay J, Steliarova-Foucher E, Lortet-Tieulent J, Rosso S, Coebergh JWW, Comber $\mathrm{H}$, et al. Cancer incidence and mortality in Europe: estimates for 40 countries in 2012. Eur J Cancer. 2013;49:1374-403.

2. Malta National Cancer Registry. Department of Health Information and Research. 2015. www.tinyurl.com/cancers-malta. Accessed 27 Apr 2017.

3. Elias N, Bou-Orm IR, Adib SM. Patterns and determinants of mammography screening in Lebanese women. Prev Med Rep. 2017:5:187-93.

4. Barth RJ Jr, Gibson GR, Carney PA, Mott LA, Becher RD, Poplack SP. Detection of breast cancer on screening mammography allows patients to be treated with less-toxic therapy. Am J Roentgenol. 2005:184:324-9.

5. Feig SA. Screening mammography controversies: resolved, partly resolved, and unresolved. Breast J. 2005;11(Suppl 1):S3-6.

6. White E, Miglioretti DL, Yankaskas BC, Geller BM, Rosenberg RD, Kerlikowske $\mathrm{K}$, et al. Biennial versus annual mammography and the risk of late-stage breast cancer. J Natl Cancer Inst. 2004;96(24):1832-9.

7. Rauscher GH, O'Malley MS, Earp JAL. How consistently do women report lifetime mammograms at successive interviews? Am J Prev Med. 2002;22(1): 8-14.

8. NHS Breast Screening Programme. Annual Review, 2012. http://webarchive. nationalarchives.gov.uk/20150505144711/http://www.cancerscreening.nhs. uk/breastscreen/publications/nhsbsp-annualreview2012.pdf. Accessed 15 Aug 2017.

9. Törnberg S, Kemetli L, Svane G, Rosén M, Stenbeck M, Nyström L. Pattern of participation in a cohort aged 50-60 at first invitation to the servicescreening programme with mammography in Stockholm county, Sweden. Prev Med. 2005;41:728-33.

10. Greif J. Mammographic screening for breast cancer: an invited review of the benefits and costs. Breast. 2010;19:268-72.

11. Mai V, Sullivan T, Chiarelli AM. Breast cancer screening program in Canada: successes and challenges. Salud Publica Mex. 2009;51(Suppl 2):s228-35.

12. Schopper D, de Wolf C. How effective are breast cancer screening programmes by mammography? Review of the current evidence. Eur J Cancer. 2009;45:1916-23.

13. European Commission. Breast cancer screening statistics. 2014. http://ec. europa.eu/eurostat/statistics-explained/index.php/Breast_cancer_screening_ statistics. Accessed 02 Feb 2016.

14. Johansson I, Berterö CM. Getting no respect: barriers to mammography for a group of Swedish women. Health Care Women Int. 2003;24(1):8-17.

15. Aro AR, de Koning HJ, Absetz $P$, Schreck M. Two distinct groups of nonattenders in an organized mammography screening program. Breast Cancer Res Treat. 2001;70(2):145-53.

16. Lagerlund M, Sontrop JM, Zackrisson S. Psychosocial factors and attendance at a population-based mammography screening program in a cohort of Swedish women. BMC Womens Health. 2014;14:33. 
17. Adib SM, Sabbah MA, Hlais S, Hanna P. Research in action: mammography utilization following breast cancer awareness campaigns in Lebanon 200205. East Mediterr Health J. 2009;15(1):6-18.

18. Jensen LF, Pedersen AF, Andersen B, Vedsted P. Identifying specific nonattending groups in breast cancer screening-population-based registry study of participation and socio-demography. BMC Cancer. 2012;12:518.

19. Marmarà D, Marmarà V, Hubbard G. Health beliefs, illness perceptions and determinants of breast screening uptake in Malta: a cross-sectional survey. BMC Public Health. 2017;17:416. https://doi.org/10.1186/s12889017-4324-6.

20. Jahanlou AS, Lotfizade M, Karami NA. A New Behavioral Model (Health Belief Model Combined with Two Fear Models): Design, Evaluation and Path Analysis of the Role of Variables in Maintaining Behavior. InTech. 2013. https://doi.org/10.5772/52966. Accessed 19 Sep 2017

21. Zhang Y. Using a Mixed Design Study to Develop a Breast Screening Intervention among Chinese Women in the UK. Doctor of Philosophy. Aston University, June 2014. http://publications.aston.ac.uk/27195/1/Zhang_ Ying_2015.pdf. Accessed 15 Aug 2017.

22. Secginli S, Nahcivan N. Factors associated with breast cancer screening behaviours in a sample of Turkish women: a questionnaire survey. Int J Nurs Stud. 2006:43:161-71.

23. Anagnostopoulos F, Dimitrakaki C, Fitzsimmons D, Potamianos G, Niakas D, Tountas $Y$. Health beliefs and illness perceptions as related to mammography uptake in randomly selected women in Greece. J Clin Psychol Med Settings. 2012;19:147-64.

24. Champion VL, Monahan PO, Springston JK, Russell K, Zollinger TW, Saywell RM Jr, et al. Measuring mammography and breast cancer beliefs in African American women. J Health Psychol. 2008;13:827-37.

25. Hale ED, Treharne GJ, Kitas GD. The common-sense model of self-regulation of health and illness: how can we use it to understand and respond to our patients' needs? Rheumatology. 2007:46(6):904-6.

26. Sutton $\mathrm{S}$. The contribution of behavioural science to primary care research development and evaluation of behaviour change interventions. Prim Health Care Res Dev. 2011;12(4):284-92.

27. von Elm E, Altman DG, Egger M, Pocock SJ, Gotzsche PC, Vandenbroucke JP. Strengthening the reporting of observational studies in epidemiology (STROBE) statement: guidelines for reporting observational studies. BMJ. 2007:335:806-8.

28. Marmarà D, Marmarà V, Hubbard G. Predicting reattendance to the second round of the Maltese National Breast Screening Programme: a prospective cohort pilot study. BMC Women's Health. 2017. in press.

29. Hersch J, Barratt A, Jansen J, Houssami N, Irwig L, Jacklyn G, et al. The effect of information about overdetection of breast cancer on women's decisionmaking about mammography screening: study protocol for a randomised controlled trial. BMJ Open. 2014;4:e004990. https://doi.org/10.1136/ bmjopen-2014-004990.

30. Chambers JA, O'Carroll RE, Cook A, Cavanagh J, Archibald D, Millar R. A pilot telephone intervention to increase uptake of breast cancer screening in socially deprived areas in Scotland (TELBRECS): study protocol for a randomised controlled trial. BMC Public Health. 2014;14:824. https://doi.org/ 10.1186/1471-2458-14-824

31. Sturges JE, Hanrahan KJ. Comparing telephone and face-to-face qualitative interviewing: a research note. Qual Res. 2004;4:107-18.

32. Moss-Morris R, Weinman J, Petrie KJ, Horne R, Cameron LD, Buick D. The revised illness perception questionnaire (IPQ-R). Psychol Health. 2002;17:1-16.

33. Champion VL. Revised susceptibility, benefits, and barriers scale for mammography screening. Res Nurs Health. 1999;22(4):341-8.

34. Marmarà D, Marmarà V, Hubbard G. Maltese translation and adaptation of Champion's Health Belief Model Scale and the Revised IIIness Perception Questionnaire for breast screening among Maltese women. J Nurs Meas. 2017;25(3):486-503. https://doi.org/10.1891/1061-3749.25.3.486.

35. Kinnear H, Rosato M, Mairs A, Hall C, O'Really D. The low uptake of breast screening in cities is a major public health issue and may be due to organisational factors: a census-based record linkage study. Breast. 2011;20:460-3.

36. McDonald JT, Sherman A. Determinants of mammography use in rural and urban regions of Canada. Can J Rural Med. 2010;15:52-60.

37. Doescher MP, Jackson JE. Trends in cervical and breast cancer screening practices among women in rural and urban areas of the United States. J Public Health Manag Pract. 2009;15:200-9.
38. Staniscia T, Manzoli LM, Di Giovanni P, Dragani V, Testa P, Cavaliere D, et al. Factors related to the uptake of breast cancer screening (mammography and breast ultrasound): a retrospective survey on a sample of resident women, 50-70 years aged, from Abruzzo region. Ann lg. 2003;15(6):1063-75.

39. Barr JK, Franks AL, Lee NC, Herther P, Schachter M. Factors associated with continued participation in mammography screening. Prev Med. 2001;33:661-7.

40. Steadman $L$, Rutter DR. Belief importance and the theory of planned behaviour: comparing modal and ranked modal beliefs in predicting attendance at breast screening. Br J Health Psychol. 2004;9(4):447-63.

41. Moser K, Patnick J, Beral V. Inequalities in reported use of breast and cervical screening in great Britain: analysis of cross sectional survey data. BMJ. 2009; 338:b2025. https://doi.org/10.1136/bmj.b2025.

42. Moodi M, Rezaeian M, Mostafavi F, Sharifirad GR. Determinants of mammography screening behavior in Iranian women: a population-based study. J Res Med Sci. 2012:17(8):750-9.

43. Allen J, Stoddard AM, Sorensen GC. Do social network characteristics predict mammography screening practices? Health Educ Behav. 2008;35(6):763-76.

44. Jepson R, Clegg A, Forbes C, Lewis R, Sowden A, Kleijnen J. The determinants of screening uptake and interventions for increasing uptake: a systematic review. Health Technology Assessment. 2000;4(14):i-vii, 1-133.

45. Lagerlund M. Factors affecting attendance at population-based mammography screening. 2002. http://publications.ki.se/xmlui/bitstream/ handle/10616/38622/thesis.pdf?sequence=1. Accessed 25 Aug 2017.

46. Tejeda S, Thompson B, Coronado GD, Martin DP. Barriers and facilitators related to mammography use among lower educated Mexican women in the USA. Soc Sci Med. 2009;68:832-9. https://doi.org/10.1016/j.socscimed. 2008.12.023.

47. Willis K. "I come because I am called": recruitment and participation in mammography screening in Uppsala, Sweden. Health Care Women Intl. 2008:29:135-50. https://doi.org/10.1080/07399330701738143.

48. Manjer AR, Emilsson UM, Zackrisson S. Non-attendance in mammography screening and women's social network: a cohort study on the influence of family composition, social support, attitudes and cancer in close relations. World J Surg Oncol. 2015;13:211. https://doi.org/10.1186/s12957-015-0623-5.

49. Dundar PE, Ozyurt BC, Erdurak K. Sociodemographic determinants of nonattendance in a population-based mammography screening program in the City of Manisa, Turkey. Sci World J. 2012;816903. doi:https://doi.org/10. 1100/2012/816903.

50. Luengo S, Lazaro P, Azcona B, Madero R, Fitch K. Use of mammography among women residing in Spanish provinces with breast cancer screening programmes. Eur J Cancer Prev. 1999;8:517-24.

51. Marton C, Choo CW. A review of theoretical models of health information seeking on the web. J Doc. 2012;68(3):330-52.

52. Young R. The household context for women's health care decisions: impacts of UK policy changes. Soc Sci Med. 1996;42(6):949-63.

53. Yoo E-Y, Robbins LS. Understanding middle-aged women's health information seeking on the web: a theoretical approach. J Am Soc Inf Sci. 2008;59(4):577-90. https://doi.org/10.1002/asi.20766.

54. Bidmon S, Terlutter R. Gender differences in searching for health information on the internet and the virtual patient-physician relationship in Germany: exploratory results on how men and women differ and why. J Med Internet Res. 2015;17(6):e156. https://doi.org/10. 2196/jmir.4127.

55. Fleming $P, O^{\prime}$ Neill $S$, Owens M, Mooney T, Fitzpatrick P. Intermittent attendance at breast cancer screening. J Public Health Res. 2013;2(2):e14. https://doi.org/10.4081/jphr.2013.e14.

56. Zackrisson S, Andersson I, Manjer J, Janzon L. Non-attendance in breast cancer screening is associated with unfavourable socio-economic circumstances and advanced carcinoma. Int J Cancer. 2004;108(5):754-60.

57. Jansen E, Daniels LA, Nicholson JM. The dynamics of parenting and early feeding-constructs and controversies: a viewpoint. Early Child Dev Care. 2012;182(8):967-81.

58. Australian Government. Research Report - Campaign Developmental Research for Breast Screening. Department of Health. 2014. http://www. health.gov.au/internet/screening/publishing.nsf/Content/ D2F8355B3C9C3107CA257E1A007D9F71/\$File/ Breast\%20Screening\%20Developmental\%20Report.pdf. Accessed 15 Jul 2017

59. Consedine NS, Magai C, Krivoshekova YS, Ryzewicz L, Neugut Al. Fear, anxiety, worry, and breast cancer screening behavior: a critical review. Cancer Epidemiol Biomark Prev. 2004;13(4):501-10. 
60. Marmarà D, Marmarà V, Hubbard G. A National Cross-Sectional Study of Adherence to Timely Mammography Use in Malta. BMC Cancer. 2017; in press

61. Fayanju OM, Kraenzle S, Drake BF, Oka M, Goodman MS. Perceived barriers to mammography among underserved women in a breast health center outreach program. Am J Surg. 2014;208(3):425-34.

62. Kee F, Telford AM, Donaghy P, O'Doherty A. Attitude or access: reasons for not attending mammography in Northern Ireland. Eur J Cancer Prev. 1992;1:311-5.

63. Passanisi N, Prout M, Holm L. The New England division tell a friend program implementation evaluation. Cancer Pract. 2001;9(Suppl 1):S64-71.

64. Kiger $\mathrm{H}$. Outreach to multiethnic, multicultural, and multilingual women for breast cancer and cervical cancer education and screening: a model using professional and volunteer staffing. Fam Community Health. 2003;26:307-18.

65. Bencivenga M, DeRubis S, Leach P, Lotito L, Shoemaker C, Lengerich EJ. Community partnerships, food pantries, and an evidence-based intervention to increase mammography among rural women. J Rural Health. 2008;24:91-5.

66. Lostao L, Joiner TE, Pettit JW, Chorot P, Sandin B. Health beliefs and illness attitudes as predictors of breast cancer screening attendance. Eur J Pub Health. 2001;11:247-79.

67. Witte K, Allen M. A meta-analysis of fear appeals: implications of effective public health campaigns. Health Educ Behav. 2000;27:591-615.

68. Baron-Epel O, Friedman N, Lernau O. Reducing disparities in mammography-use in a multicultural population in Israel. Int J Equity Health. 2009:8:19. https://doi.org/10.1186/1475-9276-8-19.

69. Austin L, Ahmad F, McNally MJ, Steward D. Breast and cervical cancer screening in Hispanic women: a literature review using the health belief model. Womens Health Issues. 2002;12:122-8.

70. Whelehan P, Evans A, Wells M, MacGillivray S. The effect of mammography pain on repeat participation in breast cancer screening: a systematic review. Breast. 2013;22:389-94.

71. Paul M. Factors that influence the uptake of Breast Cancer Screening among women of reproductive age in Mosocho division, KISII Central District, Kenya. 2012. http://ir-library.ku.ac.ke/bitstream/handle/123456789/ 6874/Macheneri\%20Paul.pdf?sequence=1. Accessed 10 Sep 2017.

72. Magai C, Consedine N, Neugut AL, Hershman DL. Common psychosocial factors underlying breast cancer screening and breast cancer treatment adherence; a conceptual review and synthesis. J Women's Health. 2007;16(1):11-23.

73. Miller LY, Hailey BJ. Cancer anxiety and breast cancer screening in African American women: a preliminary study. Women's Health Int. 1994;4:170-4.

74. Edwards NI, Jones DA. Uptake of breast cancer screening in older women. Age Ageing. 2000;29:131-5.

75. Lagerlund M, Sparén P, Thurfjell E, Ekbom A, Lambe M. Predictors of nonattendance in a population-based mammography screening programme; socio-demographic factors and aspects of health behaviour. Eur J Cancer Prev. 2000;9(1):25-33.

76. Rakowski W, Meissner H, Vernon SW, Breen N, Rimer B, Clark MA. Correlates of repeat and recent mammography for women ages 45 to 75 in the 2002 to 2003 health information National Trends Survey (HINTS 2003). Cancer Epidemiol Biomark Prev. 2006;15(11):2093-101. https://doi.org/10.1158/1055-9965.

77. Boyer BA, Cantor RK. Posttraumatic stress among women with breast cancer and their daughters: relationship with daughters' breast cancer screening. Am J Fam Ther. 2005:33:443-60.

78. Friedman LC, Webb JA, Weinberg AD, Lane M, Cooper HP, Woodruff A. Breast cancer screening: racial/ethnic differences in behaviors and beliefs. J Cancer Educ. 1995;10:213-6.

79. Shelby RA, Scipio CD, Somers TJ, Scott Soo M, Weinfurt KP, Keefe FJ. Prospective study of factors predicting adherence to surveillance mammography in women treated for breast cancer. J Clin Oncol. 2012;30(8):813-9. https://doi.org/10.1200/ JCO.2010.34.4333

80. Soler-Michel P, Courtial I, Bremond A. Reattendance of women for breast cancer screening programs. A review. Participation Secondaire Femmes Dépistage Organisé Cancer Revue Litt. 2005;53(5):549-67.

81. Dolan NC, Feinglass J, Priyanath A, Haviley C, Sorensen AV, Venta LA. Measuring satisfaction with mammography results reporting. J Gen Intern Med. 2001;16(3):157-62.
82. Marmarà DM, Curtis J, Marmarà VA. Women's satisfaction of the Maltese breast screening Programme: a cross-sectional survey. Malta Med J. 2015;27(4):13-21.

83. Miller $D$, Livingstone $V$, Herbison P. Interventions for relieving the pain and discomfort of screening mammography. Cochrane Database Syst Rev. 2008; 23(1):CD002942. https://doi.org/10.1002/14651858.CD002942.pub2.

\section{Submit your next manuscript to BioMed Central and we will help you at every step:}

- We accept pre-submission inquiries

- Our selector tool helps you to find the most relevant journal

- We provide round the clock customer support

- Convenient online submission

- Thorough peer review

- Inclusion in PubMed and all major indexing services

- Maximum visibility for your research

Submit your manuscript at www.biomedcentral.com/submit
Biomed Central 